\title{
"Frame" capture - why the war on poaching can never be won: about the John Hanks' book Operation Lock and the war on rhino poaching
}

\author{
Ray Ison ${ }^{1, *}$ and Duan Biggs ${ }^{2}$ \\ ${ }^{1}$ Professor of Systems, The Open University, UK \\ 2 Senior Research Fellow, Environmental Futures Research Institute, Griffith University, Nathan, Queensland, Australia
}

Ray Ison et Duan Biggs nous invitent ici à réfléchir à l'exigence d'une pensée systémique qui ne se contente pas de prendre la réalité comme un système. Cette pensée commence par reconsidérer la façon dont le concepteur du système se projette dans la problématique afin d'agir dans une situation complexe incluant sa propre pensée.

La Rédaction

\begin{abstract}
This essay is an extended and critical review, of John Hanks' book Operation Lock and the waron rhino poaching, which is an insider account of hitherto untold stories of a secretive undercover operation to gather intelligence to counter the ongoing slaughter of Africa's elephants and rhinos. Our critique employs the metaphor "ecology of mind", following Gregory Bateson, to highlight how so much conservation effort with an espoused focus on improving natural ecologies fails at the level of "mind", in particular the choices that are made to frame situations of concern. The outcome, we argue, is persistent framing failure. This failure, despite the efforts of Hanks with his authentic cry for more effective action, runs the risk of institutionalising systemic failure. Hanks consistently espouses support for local community as key stakeholders in the future of conservation - but his book lacks evidence of investment, good practice examples and institutional and governance reforms needed to create and sustain such initiatives. Indeed, the framing of the poaching challenge as a war presents barriers to finding systemic and sustainable solutions to the crisis.
\end{abstract}

Keywords: poaching / rhino / local communities / illegal wildlife trade / conservation / institutions / war metaphor

\begin{abstract}
Résumé - Pourquoi la guerre contre le braconnage n'a aucune chance d'aboutir: un problème de cadrage. À propos de l'ouvrage de John Hanks L'opération Lock et la guerre contre le braconnage des rhinocéros. Ce texte est une analyse critique approfondie de l'ouvrage de John Hanks Operation Lock and the war on rhino poaching, récit inédit d'une opération sous couverture à la fin des années 1980 chargée de collecter des informations visant à lutter contre le massacre des éléphants et des rhinocéros toujours en cours en Afrique. Nous employons la métaphore d'«écologie de l'esprit», introduite par Gregory Bateson, pour souligner combien tant d'efforts de conservation, dont le but déclaré est d'améliorer les écosystèmes naturels, échouent au niveau de «l'esprit», en particulier concernant les choix faits pour « cadrer» des situations préoccupantes. Cela conduit, selon nous, à des erreurs permanentes de «cadrage». Malgré le vibrant plaidoyer de Hanks en faveur d'actions plus efficaces, ces erreurs risquent d'aboutir à une institutionnalisation de l'échec systémique. Hanks défend l'idée que les communautés locales sont des acteurs-clés de l'avenir de la conservation, mais il manque dans son livre des preuves d'investissements, des exemples de bonnes pratiques et de réformes institutionnelles et de gouvernance nécessaires pour créer et soutenir de telles initiatives. En effet, envisager la lutte contre le braconnage « comme une guerre» fait obstacle à la recherche de solutions systémiques et durables à cette crise.
\end{abstract}

Mots-clés : braconnage / rhinocéros / communautés locales / commerce illégal d'espèces sauvages / conservation / institutions / métaphore de la guerre

\footnotetext{
* Corresponding author: ray.ison@open. ac.uk
} 
Ray Ison is Professor of Systems at the Open University, UK where with colleagues he is responsible for a successful taught MSc in Systems Thinking in Practice (see http://www.open.ac.uk/choose/ou/systemsthinking). He has worked in South and East Africa, particularly with the originators of strategic adaptive management within Kruger National Park.

Duan Biggs is a Senior Research Fellow at the Environmental Futures Research Institute at Griffith University in Brisbane, Australia. He is appointed as an adjunct at the ARC Centre of Excellence for Environmental Decisions, Centre for Biodiversity and Conservation Science, University of Queensland, Brisbane, Australia and at the Department of Conservation Ecology and Entomology, Stellenbosch University, South Africa. Duan was born in Namibia and grew up in South Africa's Kruger National Park where he has worked before for South African National Parks. In recent years his research has focused on how to understand and manage the illegal wildlife trade whilst meeting the needs of local communities that live with wildlife. He is active in international policy discussions on the issue.

This book", tagged as the "breaking of a 25 year silence", exemplifies an attempt at "out of the box" action gone wrong: "a sad story dominated by the gruesome realities of mutilated rhinos and compounded by some of the worst attributes of humankind". This engaging insider account, written in authentic voice, tells the hitherto untold stories of a secretive undercover operation to gather intelligence to counter the ongoing slaughter of Africa's elephants and rhinos. Operation Lock (1988-1990) included conservation and military elites: David Stirling of SAS notoriety from the British Special Forces, Prince Bernhard of the Netherlands and other conservation notables including, at the periphery, Prince Philip of the House of Windsor. Operation Lock collected information at the highest levels of African politics about who was involved in the high value illicit trade of wildlife products and used this information to design interventions many of which were secret. The conservation organisation WWF (World Wildlife Fund) played a central role. The "operation" was funded through sale of pictures owned by Queen Wilhelmina of the Netherlands and overseen by her husband, Prince Bernhard.

Hanks, then based with WWF was the main operational intermediary with Prince Bernhard. Britishborn Hanks was fascinated by Africa from a young age; following a Cambridge Natural Sciences Tripos and $\mathrm{PhD}$ in Zoology, he went on to work across African

\footnotetext{
${ }^{1}$ Hanks J., 2015. Operation Lock and the war on rhino poaching, Penguin Books.
}

conservation issues in his career including at WWF headquarters in Gland Switzerland as director of global conservation programs and in Stellenbosch South Africa as CEO of WWF South Africa. In all he has spent over 45 years working in Africa.

Hanks' central narrative is a parable of our times exemplifying all that is going wrong with human thinking and doing of the sort that concerned Bateson many years ago. It would be easy to fall into a trap of thinking that the out of control poaching of the great mega fauna is ecology out of control. But not an ecology as most now understand the term. Gregory Bateson, polymath, systems thinker, husband of Margaret Mead and son of the founder of modern genetics, William Bateson, used a more appropriate framing when he called his best remembered work Steps to an ecology of mind ${ }^{2}$. This is the ecology that is out of control and to which Hanks' book speaks as exemplified by the way the conservation community perceives, chooses to frame, and respond to the poaching crisis.

A story about an undeclared war begun in the 1960 s and which continues today is recounted; it is also a story about a war that has not been, and never will be, won. The only winning to be done is to succeed in breaking out of the trap of framing the rhino situation as a war before embarking on actions that may be systemically desirable and culturally feasible. It is around the question of reframing that our review is structured. George Lakoff has written that:

"All thinking and talking involves 'framing'. And since frames come in systems, a single word typically activates not only its defining frame, but also much of the system its defining frame is in. Moreover, many frame-circuits have direct connections to the emotional regions of the brain. Emotions are an inescapable part of normal thought. Indeed, you cannot be rational without emotions ${ }^{3}$."

Lakoff's claims are insightful as they draw attention to the consequences of framing choices. In other words it is not possible to avoid the situated and embodied nature of our engagement with the world, for which we each must take responsibility. Responsibility begins when people in a situation recognise they have agency with respect to their framing choices. Through the vehicle of the "rhino issue" we draw out the systemic implications of consistently adopting a "war" framing compared to alternatives. But there is an important point to be made first. Because, in everyday life, we lose sight of socially and culturally habituated framing choices, we have lost capacity to operationalise our agency in situations of

\footnotetext{
${ }^{2}$ Bateson G., 1972. Steps to an ecology of mind, Chicago, University of Chicago Press.

${ }^{3}$ Lakoff G., 2010. Why it matters how we frame the environment, Environmental Communication, 4, 1, p. 71.
} 
great concern like high levels of rhino and elephant poaching. The social planners Ernst Rittel and Melvin Webber invented the pair of terms "wicked" and "tame". A tame problem is one that can be solved, whereas a wicked problem is one that requires the ongoing governance and adaptive management of a complex and uncertain situation.

It is now well known that there has been consistent public policy failure because the implications of the distinctions "wicked" and "tame" have failed to be built into the practices of those who seek to govern, or for that matter seek to act purposefully in relation to, any public policy issue. From this perspective "war" is an ill-suited framing choice; war is a choice to frame the poaching crisis as a tame problem, something that is winnable or solvable. Instead war, any war, can be understood as an emergent property of the failure to govern situations usefully framed as "wicked". We emphasise that adopting a wicked or tame framing choice is not an act of categorisation; the choice needs to be understood as a choice about boundary, i.e., expanding or contracting boundary choices to incorporate the dynamics that if acted upon, or transformed, can actually make a difference.

The factors that make conserving Africa's wildlife intractable are explored at length by Hanks; to the uninitiated it is important to appreciate how the Convention on International Trade in Endangered Species of Wild Fauna and Flora (CITES) was instituted in 1977. Since then, the international trade of rhino horn of any species has been illegal. The ban on the trade in ivory was enacted in 1989, and other than special permission for one-off sales from southern African countries, trading has not been permitted. These dynamics, usefully illuminated by Hanks, constitute the current area of controversy in deciding how to act. Should CITES bans be maintained and more effort focused on investment in all the means of effective contemporary warfare? But where does the money for investment come from and how is the war to be pursued? Or should trade in horn be allowed under a regulated market? Horn can be harvested from rhino without killing the animal and if legally tradeable can also generate funds for conservation and poverty alleviation?

We have some experience of the issues at hand, primarily through connections to the main battlefield in the current theatre of war, namely Kruger Park, the jewel in South African National Parks' (SANParks') crown. Many arguments put forward by Hanks accord with our experience, especially in relation to the post-2007 surge in the poaching of rhinos, and the various (failed) attempts to manage it. Hanks argues that radical changes in the status quo are advocated before any sustainable success is likely to be experienced in conserving the continents' high value iconic species, concluding that: "the future of the continent's wildlife will be decided by Africa's people, specifically those who live with these species on a daily basis, and not by conservationists far removed from the daily struggles for survival, increasing poverty and declining food security" (p. 291). In reaching this conclusion Hanks is implicitly, if not explicitly, revealing the limitations of the war framing; he clearly situates himself in the policy and governance reform camp by acknowledging the centrality of rural people and their sustainable livelihoods and recognising that "wildlife will not survive unless it has a value and can pay its own way". His conclusions will be hard to accept by many but they are compelling.

Hanks offers the beginnings of a reframing that might take the rhino issue into an improved space; but he does not go far enough. Although both elephant and rhino are iconic species, the policy and practice dynamics for rhino and elephant differ; lumping them together is a trap in thinking and practice, as is beginning the conversation with iconic species in the first place. Instead the conversation needs to begin with habitat conservation and people-animal (or people-"nature") relations. Hanks makes many insightful observations that will help with this reframing.

\section{A more useful framing?}

In the past exaggeration of numbers of animals killed has been used to manipulate and mislead to help with fund-raising campaigns, actions Hanks describes as "dishonest and fundamentally fraudulent" (p. 116). Furthermore, the reality of the outcomes of policy differences between southern and east Africa on poaching and wildlife numbers has become badly twisted or altogether forgotten. The strategy promoted by many international NGOs is focused on bans and enforcement, and shirks at any suggestion of allocating rights of wildlife to landholders and communities to choose how they want to utilise this wildlife. Indeed, calls by South African conservation stakeholders and the government of Swaziland for a legal trade in horn have been widely condemned as an irresponsible idea that will only lead to an escalation in poaching. Facts about a rights and use-based approach to conservation paint a very different picture. By 1985 there were only 20 southern white rhino left in South Africa. They had been hunted to extinction elsewhere. Through years of effective protection, southern white rhino numbers increased to over 8,000 by 1997 and over 20,000 today ${ }^{4}$.

\footnotetext{
${ }^{4}$ Emslie R., Brooks M., 1999. African rhino: status survey and conservation action plan, Gland (Switzerland) and Cambridge (UK), IUCN.
} 
This tremendous recovery was supported by policies enabling ownership of rhino and their utilisation through activities such as trophy hunting. These use-based policies did not only benefit rhino populations: the numbers of large mammals in South Africa increased five-fold from 600,000 in the 1960 s to 2.5 million today. Similarly, a use-based approach to elephant conservation in Namibia and Zimbabwe contributed to a $166 \%$ and $425 \%$ growth in elephant numbers respectively in the space of two decades ${ }^{5}$. Kenya in contrast, instituted a complete hunting ban in 1977 and there is no private ownership of wildlife. Over two decades from the institution of the hunting ban elephant numbers decreased by nearly $90 \%$ in Kenya from 170,000 down to 20,000. Although numbers have stabilised and increased slightly since 1990 - the reality of these numbers and the implications for conservation policy are absent from NGO and media discussions. Instead, the implicit message and implication from many media reports, and the position of many international NGOs is that countries like South Africa and Zimbabwe should follow the Kenyan model. The real consequences and outcomes of these alternative policy choices are not communicated to the broader public.

Clearly an initiative that is needed is a social media platform to report what is, or is not happening, trends and patterns, conceived to maximise transparency and to avoid simplistic positioning on the issue. Something like "WildLeaks" is one such possibility. Ideally reporting to the site should be feasible as long as some verification process and/or coding is available for any claims that are made.

\section{Good investigative journalism helps}

Julian Rademeyer's Killing for profit: exposing the illegal rhino horn trade 6 is rightfully acknowledged by Hanks as complementary to his own book; Rademeyer explores the growth and exploitation of demand for rhino horn in Vietnam and, to a lesser extent, China and also unpacks distortions and exploitation within the trophy hunting sector, particularly in South Africa. On the other hand well-intentioned campaigns on social media (e.g., Avaaz, an independent, not-for-profit global campaigning organization that claims to work to ensure that the views and values of the world's people inform global decisions) run the risk of falling into un-nuanced, decontextualized, actions that carry with them their own framing limitations. Hanks rails against sloppy reporting and press manipulation. As with The Guardian's Nick

\footnotetext{
${ }^{5}$ http://mjperry.blogspot.com.au/2011/06/how-to-save-ele phants-shoot-them.html.

${ }^{6}$ Rademeyer J., 2012. Killing for profit: exposing the illegal rhino horn trade, Cape Town, Zebra Press.
}

Davies, Hanks has come to see much of the media as peddlers of distortion "and [an] industry whose task should be to filter out falsehood has become a conduit for propaganda and second hand news" (p. 163).

\section{Political spin}

Political spin has been a consistent feature involving not only governments but also conservation organisations, especially those seeking to protect brand, client and donor base and particular value or ideological positions. There has been compelling evidence for many years that "degraded agricultural land could be rehabilitated and made more productive and profitable by utilising wildlife rather than cattle" (p. 75). One only has to fly in to Hoedspruit in the South African Lowveld on the border of the Kruger National Park to appreciate how successful this strategy has been but "support for conservation on private land linked to a successful wildlife utilisation programme", has for Hanks "received far too little credit or recognition... and even today is the subject of ill-informed criticism" (p. 75).

\section{Elites operating illegally largely control both the supply-side and demand-side dynamics of poaching of both species}

Hanks' account of the role played by the family of Kenya's first president, Jomo Kenyatta, in ivory poaching (pp. 70-73) will be compelling reading for some, especially given Kenya's predisposition to burn confiscated ivory in large symbolic acts. Hanks is not impressed by such actions.

In the midst of Operation Lock, Hanks accompanied Prince Bernhard on a WWF-organised visit to meet the state presidents and senior conservation officials in Kenya, Zimbabwe, Zambia, Malawi and Tanzania. Reflecting on this experience Hanks says "although we were certainly aware of the existence of corruption at the highest level in the five countries we visited, it was only some years later that the true extent of the blatant plundering of state resources by those in power came to light". At the end of this trip Hanks reminded Prince Bernhard of one of the findings from the first "Operation Lock" report: "all the States with a rhino population have attempted to conform to some kind of prohibition and law against poaching but these actions must be seen as more of a sop to western criticism rather than a natural and sincere reaction" (p. 89).

Corruption remains a serious, ongoing impediment to dealing with this crisis, but the role of European colonisation in creating the conditions for this corruption to emerge is little recognised by Hanks nor are the 
implications of historical relationships between black ethnic groups and wildlife, particularly large and often dangerous wildlife, given attention. A question demanding attention is whether there is cultural and/or political indifference to wildlife among emergent black elites and others at local level except where they act to provide a sop to western interests? What are the dispositions within South Africa's ruling African National Congress, for example? Sadly despite the control exercised by elites it is the poacher, usually poor and easily replaced, and the rhino or elephant who are the main victims of "war".

\section{Financial flows, economics and equity}

Hanks (p. 131) building on economic analyses argues strongly that the "option of restoring a legal trade in ivory should not be dismissed out of hand. The arguments in favour of reconsidering the trade ban are gaining strength and credibility and the same argument applies to the conservation of rhino". Hanks describes his own parting of the ways with WWF over its opposition to trade and domestication, arguing, following Bonner's 1993 book At the hand of man: peril and hope for Africa's wildlife ${ }^{7}$ that the then WWF leadership completely missed the point that "not nearly enough had been done to recognise and address the realities of poverty afflicting the majority of the continent's population and that most NGOs were guilty of... a 'culturally biased Western solution"" (p. 143).

\section{Organisational jockeying, entrenched silos and poor management practices}

Within conservation organisations and ministries poor management characterised by "divide-and-rule; no loyalty to staff; excessive politisation [sic] of decisions depending on how they affect the survival struggle of a threatened DG [Director General]; no encouragement for staff - mistakes but not successes being escalated; fear reigns with staff which inhibits release of positive energies" are widespread (p. 145). To this can be added excessive silo-effects within organisations and between organisations as well as attempts at change that lack systemic insight, thus making things worse. For example, the closure of ESPU (Endangered Species Protection Unit) within the SA police by disgraced former police commissioner Jackie Selebi (p. 182): "Selebi's 'integrated approach' was supposed to work better, but it was a dismal failure". On-going organisational and institutional failure is a tragedy of the same magnitude as the loss of our mega fauna.

\footnotetext{
${ }^{7}$ Bonner R., 1993. At the hand of man: peril and hope for Africa's wildlife, London, Simon \& Schuster.
}

\section{Changing "frames" and institutions}

There are emergent themes apparent to a reader who understands the difference between framing a situation such as rhino poaching as "wicked" rather than "tame". Hanks is aware of some of these but apparently not others. For example, the most pervasive institutional arrangement that runs through Hanks' story is that of "projectification". An institution is a norm, policy, practice, "rule of the game" that we humans have invented and use either formally (e.g., projects) or informally (e.g., family meal times). "Projects" as formal devices to organise what we do began to become popular about a 100 years ago; we now live in a world where it is seemingly unimaginable that what we seek to do is not projectified! In a corrupt regime a project is a device to siphon off money; for an NGO it is a device to show action, impact, deliverables and thus build a narrative of justification to donors and policy makers. The observant reader of Hanks' book will realise that much of the time he and others were concerned with getting the next project into place, delivering on the current one and possibly, just possibly, learning and acting on the basis of the last one!

Projects as an institutional form are lousy at dealing with situations of uncertainty, complexity, interdependencies with multiple stakeholders and thus perspectives (i.e., the features of a situation that justify a "wicked" framing). Projects are also inadequate forms because they are subjected to "project management" rather than crafting new institutions that are long term and can effect systemic governance, or governing of issues that will remain relevant or of concern to a society over a long period of time (i.e., beyond the 3-4 year project and election cycle). Systemic co-inquiry and models of coresearch and co-design exemplify the shift needed as does the possibility of investing in "social learning" as an alternative governance mechanism to that of regulation and enforcement, fiscal or market mechanisms and education or information provision ${ }^{8}$.

In Hanks' story the project brings with it some other practices that undermine effectiveness. These include, knowingly or not, a widespread commitment and belief in science as the most credible and best form of knowledge ${ }^{9}$ within the main conservation organisations and in some pockets of Conservation Ministries. Good science is always necessary but never sufficient and it has often been deployed at the expense of local and

\footnotetext{
${ }^{8}$ Ison R.L., 2010. Systems practice: how to act in a climatechange world, London, Springer \& The Open University.

${ }^{9}$ Scientism is non-reflexive belief in the universal applicability of the scientific method and approach, and the view that empirical science constitutes the most "authoritative" worldview or the most valuable part of human learning - to the exclusion of other viewpoints.
} 
indigenous knowledge; decision making on the basis of modelling can similarly lead into situations of conflict (see pp. 94-95). As an issue develops over time insiders and outsiders emerge as do particular "camps" (features all too common of academic practice). Such patterns exacerbate conflict and contestation rather than collaboration and, through concerted action, transformation of the issue of concern.

Within the Operation Lock story are institutional elements and examples of practice that will continue to be needed. Firstly the issue is beyond the boundaries of any nation state thus mandating collaboration in many forms, including an ability to generate intelligence, undertake surveillance, monitor patterns, identify key actors and smuggling pathways. However these capabilities are meaningless in the absence of a platform that can orchestrate effective action and to do this there must exist a common purpose amongst political and policy elites from different countries - in the poaching dilemma no country is an island unto itself. Hanks claims that one of Operation Lock's most significant contributions to conservation efforts in southern Africa "was in training and equipping anti-poaching teams to protect rhinos in the field". He says (p. 107) "nobody can dispute that a well-trained and highly motivated APU (Anti Poaching Unit) properly equipped with weapons, radios and transport can act as a serious deterrent to poachers, especially if the unit enjoys the support of the communities adjacent to the protected areas". He argues the case for combining anti-poaching measures with "realistic programme[s] to win the support of the local population, either by employing people from the community or promoting wildlife-linked job opportunities, such as tourism or sustainable use of wildlife through hunting". He concludes that this vital component of the operation was given far too little attention, which is certainly the case. However, it could be argued that Hanks himself pays too little attention to this issue throughout the book.

A widespread phenomenon in the fields of conservation and natural resources management is the lack of attention paid to securing the learning from one project to the next, one policy maker to the next, or one government to the next. This is partly a problem of projectification and organisational silos but is more profoundly and disturbingly symptomatic of systemic failure of governance. Key actors in Operation Lock were prescient in their insight - they understood the systemic dynamics enough to claim at the end of 1989 that Mozambique would face a poaching onslaught after the end of the civil war and that after Mozambique "has been cleaned up by the poachers, they will turn their attention towards South African game reserves, such as the Kruger National Park, even if it is a tougher nut to crack" (p. 110). This is exactly what happened in 2012 and what was the response? The appointment of a retired general, a continuation of the war on a new battlefield, and the diversion of rangers and field staff in Kruger away from their roles in management to become frontline soldiers in the new battle!

Wars soak up precious investment funds depriving other fields of endeavour of funds, personnel, organisational and political support. This is the case in Kruger where a 20 year "experiment" with strategic adaptive management (SAM) has been undermined; this internationally recognised success story in harnessing new ways of thinking and acting for park governance (an innovative response to dealing with a "wicked problem") is at the moment seriously in danger of becoming a casualty of war! Had politicians and international NGOs opted for a "wicked framing" choice SAM may have been the recipient of investment to more boldly innovate by, for example, involving communities outside the current park boundaries, combining livelihood enhancement with co-governance arrangements and further breaking down siloed ways of operating.

Hanks appears to have consistently supported the place of local community as stakeholders in the future of conservation - but his book provides little evidence of investment, good practice examples and institutional and governance reforms needed to create and sustain such initiatives - this arm of policy if it has existed in any meaningful way is failing, or has failed to date. Quite clearly livelihoods and well-being transcend the boundaries and policies of the nation state - so concerted action across boundaries is needed. Kruger would be a good place to start building on the legacy, such as it is, of strategic adaptive management re-framed as systemic and adaptive co-governing. The way forward requires real partnerships between international donors, NGOs, and communities that explicitly recognise and account for the points above. This necessitates greater investment into partnership building with on-ground communities as well as governments, and processes that support this over $10-20$ year time horizons at minimum. The alternative is to persist with the war metaphor and its enactment, the habituated response with no end in sight as to when this framing and strategy may actually turn the poaching crisis around. Significantly the "current war" is not even a contemporary version of war, which would be a war conducted through satellites and cyber-espionage (at least that we know of - hints in his book suggest it may be otherwise).

There is already evidence that the "war" framing is migrating into a "terror" variation - incorporating the war on rhinos into a sphere of action in the greater war on terror. There is compelling evidence historically that insurgency movements poached animals, especially for ivory, to fund their military activity. There is little doubt, 
given the money that can be realised, that similar activities exist now. However, further militarisation is unlikely in the long run to secure the hearts and minds of those whose livelihoods are at risk on a daily basis. Can we persist with so much resource devoted to a defence/ fortress strategy where the primary target is the poacher? Hanks argues that the identities of the kingpings behind the illegal trade are known but nobody dares to name them. Thus, "failure to enforce laws is no reason to introduce new ones. This is political failure" (p. 205).

Hanks argues that "it is not a question of either a community approach or a military approach for every situation. Both have a very important role to play and they should not be seen as mutually exclusive" (p. 192). In defending himself against being wedded to a military imperialistic approach Hanks cites extracts from Raymond Bonner's At the hand of man quoting him as saying: "at all costs, we must avoid planning upon people, telling them what to do without any form of consultation whatsoever". Unfortunately most attempts at consultation are poorly conducted and are rarely deepened into active participation and co-design or cogovernance models that generate sustained social learning, and new institutions, new rules and thus understandings and practices for governance reform. The tragedy unfolding is that SAM held this promise. Hanks is too quiet on this front, as exemplified by the paucity of case studies on which he draws. Mandela, who Hanks claims was supportive of conservation, said in an interview: "It is important for conservation and rural development to be combined. Conservationists must take into account the needs of people around the reserves. They need to encourage education programmes about protecting wildlife and always act in co-operation with the local communities" (p.193). Despite repeated avowals, Hanks persists in putting in-the-field-protection at the top of his list for investment and action. As he acknowledges "this is easier said than done" and because "throughout Africa wildlife conservation is viewed as a luxury in the face of mounting external debt, rising unemployment, and increasing demand for housing, health facilities and free education, exacerbated by high rates of inflation and declining terms of trade" we suggest other strategies need to be prioritised and pursued.

If all concerned actors with a stake in the rhino issue were to pay attention to their framing choices and engage in deliberative, cooperative governance innovation then it might be possible to arrive at accommodations of difference on the basis that: "there is no single solution to addressing the growing illegal trade in rhino horn, in spite of some of the regrettably naive options promoted by genuinely concerned individuals" and "most of the actions that may be taken fall outside the ambit of the professional conservationists and are rarely addressed or even mentioned by the majority of environmental NGOs". Hanks knows that effective action "is the province of no one organisation" and that "complexity is overlooked or ignored" (p. 203). Grasping for a viable future he suggests that: "Perhaps some new words are needed in the daily soup of conservation vocabulary, not just for the sake of novelty or change, but to stimulate a new way of thinking about the issues of concern". We suggest that whilst necessary this is far too limited an ambition; the requisite concepts and practices already exist but they are not deployed in ways that give rise to the emergence of an "ecology of mind" able to break through the limitations of historical framings, practices and understandings and, which through enacting our concerns for the future of the megafauna, transforms who we are in the process.

Cite this article as: Ison R., Biggs D., 2017. "Frame" capture - why the war on poaching can never be won: about the John Hanks' book Operation Lock and the war on rhino poaching. Nat. Sci. Soc. 25, 1, 63-69. 